\title{
Reading Too Much and Too Little into the Matter? Latent Limits and Potentials of EU Freedom of Movement
}

\author{
Julija Sardelić
}

This EUDO-Citizenship debate has shown that EU freedom of movement is under attack. As Rainer Bauböck highlighted in his contribution, the outcome of the EU membership referendum in the UK casts a 'long and dark shadow' over any debate on EU freedom of movement. However, EU freedom of movement still has as many defenders as attackers on the legal, political and academic fronts, as well as in practical everyday contexts. As did Vesco Paskalev, I want to start this contribution with my own personal experience: I am a Slovenian citizen, who studied and worked in EU Member States other than my own, such as Hungary, Italy and the United Kingdom, where I currently reside. I have personally benefited from the rights granted to me under the EU Freedom of Movement Directive (2004/38/EC). This made it a lot easier to be mobile across the EU than it has been for my nonEU colleagues. And with the Brexit vote, I contemplate what my own position will be as a non-UK EU national living and working in the UK in the long run.

In this contribution I aim to show that both attackers and defenders of free movement share some presumptions in their arguments. In the debate on free movement both often read too much into the potential of freedom of movement and underestimate its limits. At the same time, they are not sufficiently aware of the potential injustice freedom of movement produces as a side effect. I will illustrate both of my claims by focusing on the position of marginalized minorities, who have often been in at the centre of public anxieties about EU freedom of movement.

Floris de Witte argues that EU freedom of movement is important not only from a state, but also from an individual perspective because it offers opportunities for emancipation as well as a 'recalibration of justice and democracy' beyond the state level. Both of his points are well illustrated by his example of an LGBT couple, who move from one EU Member State to another in order to get their union recognised and to lead a life with reduced risk of discrimination. In my view, this example shows how we can read too 
much into the potential of free movement and underestimate its limits to deliver justice. First, the question is how many EU citizens have genuine access to this right. To give a banal example, it will be a lot easier for a middle-class educated and employed LGBT individual from Zagreb to access it than an impoverished lower-class lesbian or gay man from a rural area in southeast Poland. This is not simply a question of economic means, which De Witte already indicated, but also of the social and cultural capital individuals possess according to Pierre Bourdieu. ${ }^{1}$ Having a right does not necessarily mean that you have a possibility to access it and that you will indeed do so. Second, I wonder whether freedom of movement can be the main instrument for overcoming inequalities and discrimination marginalized minorities face in the EU, if they are not tackled at the state level first. Is it in fact emancipation and recalibration of justice, when the only option for an LGBT couple is to 'flee' their own country to avoid discrimination?

Saara Koikkalainen investigates the development of EU freedom of movement from its inception within the European Coal and Steal Community, where it followed a strictly economic reasoning. It has only later developed as a fundamental right of all EU citizens. Still this fundamental right is not without restrictions, which are laid down in Directive 2004/38/EC. Article 14 in the Directive states that EU migrants should not represent 'an unreasonable burden on a social assistance system of the host Member State'. Strictly legally speaking, Martijn Van Den Brink is correct, that CJEU case C-333/13 Elisabeta Dano v Jobcenter Leipzig was in accordance with this article and did deliver justice. But the question is whether the consequences of such decision are just. De Witte and Bellamy both claimed the UK-EU 'emergency brake' has very little to do with justice but a lot to do with economic reasoning. I would add that it contributed to the prevalent belief that many EU migrants in the UK are in fact 'benefit tourists'. This belief goes beyond mere economic arguments and is based on sometimes latent and sometimes open xenophobia.

The debates on 'benefit tourism' are manifestly closely related to the question whether socio-economic disparities within the EU should be primarily addressed through freedom of movement. Are the member states responsible for flattening them or should they be targeted also at the EU level? Many researchers ${ }^{2}$ showed how the debate about benefit tourism

Bourdieu, P. (1984), Distinction. Cambridge, Mass.: Harvard University Press.

2 Parker, O. (2012), 'Roma And The Politics Of EU Citizenship In France:

Everyday Security And Resistance', JCMS: Journal of Common Market

Studies 50 (3): 475-491; Sardelic, J. (2017), 'The Position And Agency Of The

"Irregularized": Romani Migrants As European Semi-Citizens', Politics 37 (3):

332-346. 
particularly highlighted the position of another marginalized minority in the EU: Romani migrants. Before 2014 British newspapers were implying that once the work restrictions for Romanian and Bulgarian citizens were been lifted, the UK would face an 'invasion of Roma'. Newspapers such as Daily Mail adopted a xenophobic stance toward Romani migrants with headlines such as "Roma already "defecating at our doorsteps." 3

Such reporting reinforced a common misconception that Roma have a propensity to migrate from post-socialist EU Member States to the more prosperous ones, where they would become a burden on the social welfare systems. In accordance with the 1993 Copenhagen Criteria, the EU paid particular attention to the minority protection of Roma in the post-socialist countries, which had a candidate country status before joining the EU in 2004 and 2007 respectively. As some scholars argued, ${ }^{4}$ this was not merely out of humanitarian concern for this marginalized population. Such emphasis on the position of Roma was also present because of the fear that once the EU free movement policy was coupled with perceived Romani nomadism and discrimination in their own states it would become a conglomerate of push and pull factors for 'Romani mass migration'.

However, this is another clear example of reading too much into the potential of EU freedom of movement. According to the very small number of available studies, such as the one by Elspeth Guild and Claude Cahn, ${ }^{5}$ Romani migrants represent a miniscule proportion of all EU migrants. In addition, their migration cannot be explained simply by the theory of push and pull factors. It also does not clearly fit the presumption that EU freedom of movement is flattening socio-economic disparities between EU Member States especially for the poorest individuals. According to the study by Maria Pantea, Romani individuals who belong to the 'poorest of the poor' are among the most immobile EU citizens. Maria Pantea argued that Romani

3 'Roma already in Britain "are defecating on people's doorsteps" says top Tory council leader as she warns of burden that Romanian and Bulgarian immigrants will place on public services', Mail Online, 31 December 2013, available at http://www.dailymail.co.uk/news/article-2531793/

Roma-Britain-defecating-peoples-doorsteps-says-Tory-council-leader-warnsburden-Romanian-Bulgarian-immigrants-place-public-services.html.

4 Kymlicka, W. (2007), Multicultural Odysseys. Oxford: Oxford University Press.

5 Cahn, C. \& E. Guild (2010), 'Recent migration of Roma in Europe', $2^{\text {nd }}$ edition, OSCE High Commissioner on National Minorities and Council of Europe Commissioner for Human Rights, available at: https://www.gfmd.org/ recent-migration-roma-europe-claude-cahn-and-elspeth-guild. 
EU migrants have certain economic resources, but even more importantly 'social ties at work' ${ }^{6}$ and networks that make their mobilities possible. This is something immobile Romani EU citizens lack.

Considering the position of EU Romani migrants, we can see that in practice EU free movement does not necessarily address injustices produced by nation states. In fact, it can also result in new injustice that is not present on the nation-state level, as De Witte argued. The French L'affaire des Roms showed what measures the French authorities have taken to deport 'unwanted' EU Romani migrants. Among these was the collective demolition of their settlements. We read too little into the potential of EU freedom of movement if we only think of it as a source of 'recalibration of justice'. The official stance of EU freedom of movement is still to a certain extent connected to the economy, but Romani migrants can be deported in case they are also labelled as being a threat to public security and order. Here both opponents and proponents of freedom of movement are reading too little into the matter, if they think this is only a question of economy and if they downplay the sentiments based on xenophobia towards Roma. Although many Romani migrants are labelled as economically inactive, they are only inactive on the official labour market. According to the 2015 Eurobarometer on Discrimination ${ }^{7}$ the stigmatization of Roma is so strong in virtually all EU Member States that most of them are not able to get work in the official economy and therefore find employment in unrecognized alternative economic niches. Some studies have shown that many EU Romani migrants end up as irregular workers without employment contracts or even in forced labour $^{8}$ as victims of human trafficking. While they are able to migrate because of the EU Directive on Freedom of Movement, they do not benefit from the EU Framework Directive (1989/391/EEC) on safety and health at work and face additional layers of inequality.

Despite the many objections listed above, I still concur with those who claim that EU free movement should be defended on a normative as well as practical level. But it is only so much that EU freedom of movement can deliver. We cannot expect that as a standalone policy it would 'recalibrate

6 Pantea, M. (2012), 'Social Ties At Work: Roma Migrants And The Community Dynamics', Ethnic and Racial Studies 36 (11): 1726-1744.

7 Available at http://ec.europa.eu/justice/fundamental-rights/files/factsheet_eurobarometer_fundamental_rights_2015.pdf.

8 Dwyer, P., H. Lewis, L. Scullion \& L. Waite (2011), 'Forced labour and UK immigration policy: status matters?', JRF programme paper: Forced labour, avaialable at https://ec.europa.eu/anti-trafficking/sites/antitrafficking/files/ forced_labour_and_uk_immigration_policy._status_matters_1.pdf. 
justice' for marginalized minorities in the EU, on the one hand. On the other hand, we should take into account that the EU free movement policy does not only belong within a strictly legal domain but has broader societal implications for questions of justice. The Brexit vote showed that EU freedom of movement should be constantly debated and renegotiated not only as a core of EU citizenship, but also beyond that core. This would not imply limiting it, but thinking about it from a global justice perspective. As Sarah Fine's contribution suggests, this perspective would ask us to consider whether EU citizens should be given a privilege of free movement over all other residents who did not draw the most favourable ticket in the citizenship birthright lottery. ${ }^{9}$

Open Access This chapter is licensed under the terms of the Creative Commons Attribution 4.0 International License (http://creativecommons.org/licenses/by/4.0/), which permits use, sharing, adaptation, distribution and reproduction in any medium or format, as long as you give appropriate credit to the original author(s) and the source, provide a link to the Creative Commons license and indicate if changes were made.

The images or other third party material in this chapter are included in the chapter's Creative Commons license, unless indicated otherwise in a credit line to the material. If material is not included in the chapter's Creative Commons license and your intended use is not permitted by statutory regulation or exceeds the permitted use, you will need to obtain permission directly from the copyright holder.

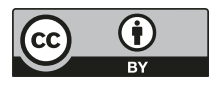

9 Shachar, A. (2009), The Birthright Lottery. Cambridge, Mass.: Harvard University Press. 